\title{
Seasonal variation of in situ feeding rates by the temperate ascidian Halocynthia papillosa
}

\author{
Marta Ribes*, Rafel Coma, Josep-Maria Gili \\ Institut de Ciències del Mar (CSIC), Passeig Joan de Borbó s/n, E-08039 Barcelona, Spain
}

\begin{abstract}
The natural diet and prey capture rate of the temperate ascidian Halocynthia papillosa were studied in the field in a Western Mediterranean population. In situ grazing rates on dissolved organic carbon, detrital particulate organic carbon, procaryotes, pico- and nanoeucaryotes, phytoplankton and ciliates were examined through a year cycle. The natural diet of the species included detrital organic matter, heterotrophic bacteria, Prochlorococcus sp., Synechococcus sp. (cyanobacteria type), protozoa and phytoplankton with a mean size range from $0.6 \pm 0.3$ (heterotrophic bacteria) to $70 \pm 22 \mu \mathrm{m}$ (pennate diatoms). Specific clearance rates varied seasonally and exhibited a pattern of increase with temperature increase in which temperature explained $55 \%$ of the variance in clearance rate throughout the year. Annual variation in prey concentration did not affect specific clearance rate. Ingestion rate of the species showed a marked seasonal pattern which was different for the 2 main food sources: detrital and live particles. Thus, while the highest ingestion of detrital particles was in spring, the highest values of Live particle ingestion occurred during summer and fall. Overall, an $H$. papillosa specimen of mean size $0.25 \mathrm{~g}$ AFDW (ash-free dry weight) was estimated to ingest an annual mean of $1305 \pm 496 \mu \mathrm{g} \mathrm{C} \mathrm{g} \mathrm{AFDW} W^{-1} \mathrm{~h}^{-1}$ and $84 \pm 16 \mu \mathrm{g} \mathrm{N} \mathrm{AFDW}^{-1} \mathrm{~h}^{-1}$ Carbon from detrital origin accounted for $92 \pm 2 \%$ of the total ingested carbon, while ingestion of live carbon accounted for $8 \pm 2 \%$. However, the seasonal variation of ingested nitrogen from live particles explained $91 \%$ of the gonadal development variance for the year, suggesting that live particles are likely to be of more significance in the diet of the species than particles from detrital origin. Feeding rates are discussed in relation to seasonal changes in food availability and production of the species (i.e. growth and reproduction). The results suggest that factors other than food availability determine the seasonal dynamics of the species.
\end{abstract}

KEY WORDS: Diet $\cdot$ Feeding behavior $\cdot$ Prey capture $\cdot$ Ascidians - Mediterranean

\section{INTRODUCTION}

Benthic suspension feeders account for an important fraction of the biomass and production in coastal marine ecosystems (Cloem 1982, Officer et al. 1982, Hily 1991). Recently, several studies have indicated that these organisms play an important role in plankton-benthos coupling (e.g. Jørgensen 1990, Gili \& Coma 1998). Ascidians, together with sponges and molluscs, are among the groups better represented in hard substrate communities in littoral zones such as tropical areas (Koike \& Suzuki 1996), temperate seas (Ramos 1988, Turon 1990a, Petersen \& Riisgård 1992), kelp beds (Newell et al. 1982), and Antarctic waters (Gerdes et al. 1992)

\footnotetext{
•E-mail: mribes@icm.csic.es
}

In general, growth and reproduction of benthic suspension feeders in tropical, temperate and polar seas are characterized by strong seasonality (e.g. Millar 1971, Clarke 1987, Harrison \& Wallace 1990). In the case of ascidians in the Western Mediterranean, 2 characteristic patterns have been distinguished. First, several colonial ascidians have been found to concentrate growth and reproduction around the winter season (i.e. autumn, winter and spring; Turon 1988, Turon \& Becerro 1992), with non-feeding periods exhibited by some species during the warm period (Turon 1988 , 1992). Second, the few solitary ascidians which have been studied in contrast show maximum reproductive activity during, or at the end of, the summer period (Becerro \& Turon 1992). This fact is surprising because, in seasonal environments, the highest new production (i.e. growth and reproduction) usually occurs during 
periods of no limitation by external factors (i.e. temperature and food availability), and the Western Mediterranean in summer is characterized by oligotrophy and low seston concentration (Zabala \& Ballesteros 1989) However, a lack of knowledge of diet and grazing rate in nature has become a barrier to the understanding of the factors that determine the dynamics of these species.

Ascidians, as sessile suspension feeders, are nutritionally dependent on the surrounding water which provides them with their resources. As a group, they are considered to be non-selective filter feeders able to capture particles from 0.5 to $100 \mu \mathrm{m}$ (Fiala-Médioni 1987), with high retention efficiency for particles larger than $0.6 \mu \mathrm{m}$ (Fiala-Médioni 1978a, Randlov \& Riisgård 1979, Stuart \& Klumpp 1984). The filtration rates of ascidians have been shown to be dependent on external factors such as temperature, oxygen tension, and food concentration, as well as on morphological factors such as body size (Fiala-Médioni 1978c, 1979a, b, Robbins 1983, Klumpp 1984, Petersen \& Riisgård 1992). However, most of these studies have been carried out under laboratory conditions and with simplified diets (FialaMédioni 1978c, Randløv \& Riisgård 1979, Robbins 1983, Petersen \& Riisgård 1992, Petersen et al. 1995). These works have provided an understanding of the physical and biological factors that affect feeding activity of ascidians. However, the difficulty of estimating feeding in nature and its seasonal variation from laboratory results (Jørgensen 1975, Okamura 1990, Vogel 1994) points to the need for studies focused on the examination of natural feeding rates.

Halocynthia papillosa (Linnaeus) is one of the most common solitary species on the rocky littoral of the North Western Mediterranean (Fiala-Médionj 1972, Turon 1990a). H. papillosa is an hermaphroditic species that reproduces once per year in late summer. Although it has continuous vitellogenesis throughout the year, gonad development is higher from March to September for ovaries and from July to September for testes (Becerro \& Turon 1992). The main objectives of this study were to determine the role of DOC (dissolved organic carbon), detrital POC (particulate organic carbon) and live carbon from different taxa as food sources for the ascidian, and to contribute to the knowledge of factors that determine the temporal variability in production of benthic suspension feeders living in seasonal environments. The natural diet and grazing rates of $H$. papillosa were examined by in situ incubations with the whole natural spectrum of food sources (DOC, detrital POC, procaryotes, pico- and nanoeucaryotes, phytoplankton and ciliates). Feeding on these potential food sources was assessed seasonally in order to cover the natural range of food abundance and composition.

\section{MATERIAL AND METHODS}

Feeding experiments were conduced in situ using continuous flow incubation chambers at the Medes Islands Marine Reserve (NW Mediterranean Sea, $42^{\circ} 3^{\prime} \mathrm{N}, 3^{\circ} 13^{\prime} \mathrm{E}$ ) from October 1995 to November 1996. Incubations were carried out in hemispherical UVtransparent Plexiglas chambers approximately 31 in volume. The chambers ( 1 experimental, with ascidian [Fig. 1a], and 1 control [Fig. 1b]) were placed on the sea bottom at $15 \mathrm{~m}$ depth and water was recirculated with a pump at a speed of $1.2 \mathrm{~cm} \mathrm{~s}^{-1}$ (this flow becomes turbulent inside the chambers) (Fig. 1c). Plastic fasteners with hooks securely anchor the chambers (see Fig. 1d). The plastic fasteners were also used to attach the chambers to the bottom by means of elastic bands between them and permanent nails located on the bottom. Close to the pump propeller, a submersible polarographic oxygen and temperature probe (Clarke-type oxygen probe, WTW EOT-196) was connected (Fig. 1e). Oxygen concentration and temperature during the incubations were monitored in both chambers. Halocynthia papillosa specimens were removed from their natural substratum and attached to PVC posts $(2 \mathrm{~cm}$. in diameter, $2.5 \mathrm{~cm}$ tall) with an inert cement 1 mo before the experiments and kept in their natural environment with conspecifics. All specimens were selected to have a similar size $10.25 \pm 0.08 \mathrm{~g}$ ash-free dry weight, AFDW; $0.33 \pm 0.1 .1 \mathrm{~g}$ dry weight, DW; $0.09 \pm 0.03 \mathrm{~g} \mathrm{DW}$ without tunic) in order to avoid the effect of size on the feeding behavior (Robbins 1983, Klumpp 1984, Petersen \& Riisgård 1992). At the beginning of each experiment, an $H$. papillosa specimen was placed on the

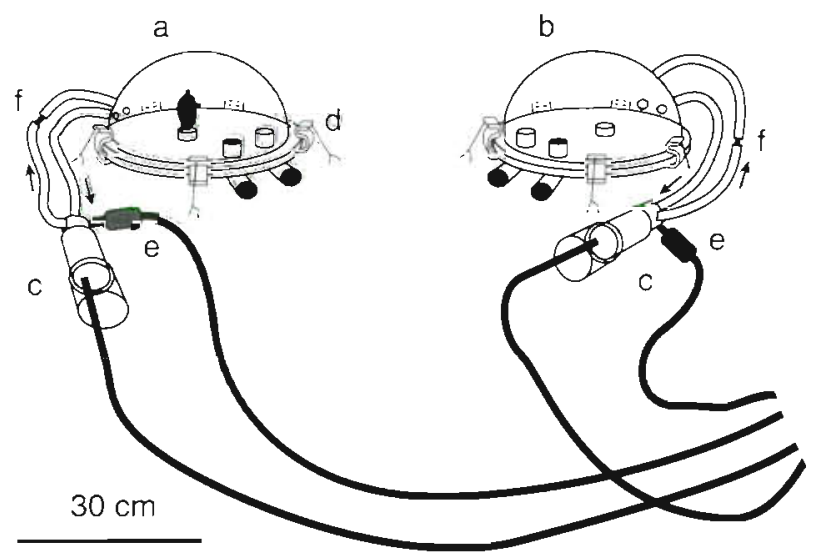

Fig. 1. General view of the experimental set-up for incubation experiments. (a) Experimental chamber with the ascidian specimen, (b) control chamber, (c) flow pumps with oxygen electrodes (e). (d) plastic fasteners with hooks to securely anchor the chambers, (f) PVC piece connecting inlet and outlet apertures of the chambers. When PVC piece (f) is not connected it allows outside water to circulate throughout the chambers 
base of the experimental chamber and both experimental and control chambers were closed while allowing outside water to circulate throughout the chambers (Fig. 1f). An acclimatization period of $2 \mathrm{~h}$ was left to avoid the lag-phase phenomenon (Petersen \& Riisgård 1992). After this acclimatization, 3 replicate water samples of $500 \mathrm{ml}$ were collected from both chambers (initial water samples) and the flow of both chambers was forced to recirculate within the system. Water samples were preserved for further analysis (see below). Two hours later, 3 replicate water samples were collected again from both chambers (final water samples). Grazing was calculated from the decrease in prey concentration in the experimental chamber relative to the control chamber. The potential prey items included: procaryotes (heterotrophic bacteria, Synechococcus sp., and Prochlorococcus sp.), pico- and nanoeucaryotes, ciliates, phytoplankton (diatoms and dinoflagellates), DOC and detrital POC. Water volume used for the analysis of DOC, POC, procaryotes, and pico- and nanoeucaryotes was previously screened by a $100 \mu \mathrm{m}$ net to avoid larger plankters. Five experiments were carried out each season, and therefore a total of 20 experiments were performed throughout the year cycle

To quantify heterotrophic bacteria, Prochlorococcus sp., Synechococcus sp., and pico- and nanoeucaryotes we used flow cytometry. Two ml water samples from the incubation chambers were preserved for flow cytometry by standard protocols (Campbell et al. 1994), frozen in liquid nitrogen, and stored at $-80^{\circ} \mathrm{C}$ or in dry ice. Samples were analyzed using a Coulter EPICS 753 flow cytometer (Coulter Electronics Corporation, Hialeah, Florida) equipped with two $5 \mathrm{~W}$ argon lasers and a Micro-Sampler-Delivery-System. The flow cytometer was set up for UV $(220 \mathrm{~mW})$ and $488 \mathrm{~nm}$ $(1 \mathrm{~W})$ colinear analysis. Hoechst 33342 (DNA-specific fluorochrome) was used to stain DNA according to Monger \& Landry (1993). Five parameters were collected in list mode and analyzed with custom-designed software (CYTOPC by Daniel Vaulot): red fluorescence (from chlorophyll a), orange fluorescence (from phycoerythrin), blue fluorescence (from DNA stained with Hoechst 33342), forward- and right-angle light scatter signals (FALS and RALS). For statistical purposes sample size for analysis was chosen to provide more than 10000 counts sample ${ }^{-1}$, then $1 \mathrm{ml}$ of sample was analyzed for picoeucaryotes and nanoeucaryotes and $100 \mu \mathrm{l}$ for heterotrophic bacteria, Prochlorococcus sp., and Synechococcus sp.

In order to measure cell sizes (length and width) of heterotrophic bacteria, Synechococcus sp., and picoand nanoeucaryotes, subsamples of $20 \mathrm{ml}$ were stained with DAPI and passed through a $0.2 \mu \mathrm{m}$ filter. For heterotrophic bacteria size estimation, over 100 cells were measured using software for image analysis as described in Massana et al. (1997). For Synechococcus sp. and pico- and nanoeucaryote size estimation, cell length and width were measured with a micrometer. Picoeucaryotes included naked flagellates smaller than $2 \mu \mathrm{m}$ and nanoeucaryotes included naked flagellates larger than $2 \mu \mathrm{m}$ as well as small dinoflagellates (unable to be distinguished with an inverted microscope) and coccolithophores (unable to be counted with acid Lugol's solution) (see below). It was not possible to measure Prochlorococcus sp. due to the difficulty of observing these cells with epifluorescence microscopy, so a mean size of $0.7 \mu \mathrm{m}$, as calculated for this species in the Mediterranean by Vaulot et al. (1990), was used.

To quantify phytoplankton and ciliate cell numbers, $350 \mathrm{ml}$ water samples were preserved with acid Lugol's solution (1\% final concentration). Subsamples of $100 \mathrm{ml}$ were settled in settling chambers, and the major groups of nano- and microphytoplankton were quantified under an inverted microscope. The microscope was connected to a color CCD video camera and a video recorder. Images of the organisms for measurement were recorded on tape and digitized with a framegrabber. Size of the organisms was determined by image analysis software (NIH [National Institute of Health]-image). For each subsample 20 individuals of the most common groups were measured. Volumes were estimated from length and width measurements assuming ellipsoidal or cylindrical shapes (Edler 1979).

POC was measured by filtering $60 \mathrm{ml}$ water samples onto pre-combusted glass fiber filters (Whatman GF/F 1825 025). Filters were then frozen in liquid nitrogen and kept at $-80^{\circ} \mathrm{C}$ until analysis. Prior to analysis, filters were dried at $60^{\circ} \mathrm{C}$ for $24 \mathrm{~h}$ and exposed to $\mathrm{HCl}$ vapors for $48 \mathrm{~h}$ in order to destroy inorganic material. Then filters were dried again and analyzed with a $\mathrm{C}: \mathrm{H}: \mathrm{N}$ autoanalyser (Perkin-Elmer 240). POC measurements included both detrital and live carbon. Detrital POC was estimated as the difference between total POC (C:H:N analysis) and total live carbon (estimated from cell counts and cell measurements).

For DOC, $20 \mathrm{ml}$ water samples were filtered through pre-combusted glass fiber filters (Whatman GF/F 1825 025). The filtered water was stored in glass tubes at $-20^{\circ} \mathrm{C}$ until analysis. Analysis was conducted by hightemperature catalytic oxidation with an autoanalyser (Shimadzu TOC-5000).

Depletion rates of the plankton were calculated assuming exponential growth and clearance of prey (Frost 1972, Saiz 1993, Ribes 1998). The prey growth rate $k\left(\mathrm{~h}^{-1}\right)$ is computed thus:

$$
k=\frac{\ln \left(C_{1} / C_{0}\right)}{t_{1}-t_{0}}
$$

where $C_{0}$ and $C_{1}$ are the prey concentrations in the chamber at the initial time $t_{0}$ and at the final time $t_{1}$. 
The clearance rate $F$ (volume swept clear biomass ${ }^{-1}$ time $^{-1}$ ) is computed as follows:

$$
F=V \frac{g}{b}
$$

where $V$ is the volume of the chamber, $b$ is the ascidian biomass ( $g$ AFDW) and $g$ is the grazing coefficient $\left(\mathrm{h}^{-1}\right)$, computed as:

$$
g=k_{\mathrm{c}}-k_{\mathrm{a}}
$$

where $k_{c}$ is the prey growth rate in the control chamber, and $k_{\alpha}$ is the apparent growth in the chamber with the ascidian. Finally, the ingestion rate, $I$ (prey ingested biomass ${ }^{-1}$ time $^{-1}$ ), is:

$$
I=F C
$$

where $C$ is the prey concentration.

The significance of predation on each kind of prey was tested by comparing growth rates of prey in control and experimental chambers with a 2-tailed Wilcoxon test (Sokal \& Rohlf 1981). Cell biovolume was calculated from length and width by approximation to the nearest geometric shape. Carbon content was then estimated from literature conversion factors as follows: heterotrophic bacteria, $0.22 \mathrm{pg} \mathrm{C} \mu \mathrm{m}^{-3}$ (Fry 1988); Prochlorococcus, $0.133 \mathrm{pg} \mathrm{C} \mu^{-3}$ (Simon \& Azam 1989); Synechococcus, $0.357 \mathrm{pg} \mathrm{C} \mathrm{mm}^{-3}$ (mean value of: Björnsen 1986, Kana \& Glibert 1987, Verity et al. 1992); pico- and nanoeucaryotes, pg $\mathrm{C}=0.433 \times\left(\mathrm{\mu m}^{3}\right)^{0.863}$ (Verity et al. 1992); phytoplankton, pg C cell ${ }^{-1}=0.109$ $\times\left(\mu^{3}\right)^{0.991}$ (Montagnes et al. 1994); ciliates, $0.19 \mathrm{pg} \mathrm{C}$ $\mu \mathrm{m}^{-3}$ (Putt \& Stoecker 1989).

Feces were obtained from inside the chamber in several experiments. They were collected with a Pasteur pipette and frozen in liquid nitrogen. Ten pieces of feces from different days were dehydrated in graded ethanol. Afterwards, they were dried by the critical point method (using $\mathrm{CO}_{2}$ as transition fluid), mounted on aluminum stubs and coated with gold in a sputter coater. Observation were done with a Hitachi S-570 scanning electron microscope (SEM). Halocynthia papillosa dry weight was determined for all incubated specimens by drying at $90^{\circ} \mathrm{C}$ for $24 \mathrm{~h}$ and ash-free dry weight was determined by combustion at $450^{\circ} \mathrm{C}$ for $5 \mathrm{~h}$. The relationship between total dry weight and dry weight without test was established by dissecting 10 specimens and drying separately the test and the mantle at $90^{\circ} \mathrm{C}$ for $24 \mathrm{~h}$. In average, dry weight without test was a $27 \pm 6 \%$ of total dry weight.

Multiple regression analysis was used in order to establish the percentage of the variance of the estimated clearance rates that could be explained by the independent factors which were monitored during each experiment, which were water temperature $\left({ }^{\circ} \mathrm{C}\right.$, recorded using a WTW oxygen electrode model EOT 196) and initial food concentration (cells $\mathrm{ml}^{-1}$ for the live particles and $\mu \mathrm{g} \mathrm{Cl}^{-1}$ for detrital particles). A backward stepwise procedure was used to exclude variables that were not relevant (Sokal \& Rohlf 1981). Variables were square root transformed when normality (Kolmogorov-Smirnov test) and/or the heteroscedasticity (Levene's test) requirements were not fulfilled.

In order to determine whether or not the species exhibits seasonality in growth, Halocynthia papillosa growth rate was estimated from changes in area of the individuals over time based on photographic monitoring. Large $H$. papillosa specimens are highly sensitive to small perturbations, such as the approach of a camera, which produce a reaction of contraction. Thus, it is difficult to photograph specimens in a state of full expansion. Small specimens of the species were observed to be much less sensitive to the same kind of perturbations. Therefore, $11 \mathrm{H}$. papillosa individuals smaller than $1 \mathrm{~cm}$ were mapped in the studied area. These individuals were photographed every 3 to 4 mo: March 1997, June 1997, October 1997 and February 1998. Size $\left(\mathrm{mm}^{2}\right)$ of the individuals viewed from the side was determined using image analysis software (NlH-image). Growth rate $\left(G r, \mathrm{~d}^{-1}\right)$ was calculated by Eq. (5) as the change in area of every individual during each time interval:

$$
G r=\frac{\ln \left(A_{1} / A_{0}\right)}{t_{1}-t_{0}}
$$

where $A_{0}$ and $A_{1}$ are the ascidian areas at the initial time $t_{0}$ and at the final time $t_{1}$.

\section{RESULTS}

All sources of $\mathrm{POC}<100 \mu \mathrm{m}$, both live (i.e. recognizable cells) and detrital, that were potentially available as food as well as DOC were considered in this study. The taxa distinguished within the live carbon category were: heterotrophic bacteria, Prochlorococcus sp., Synechococcus sp., pico- and nanoeucaryotes, phytoplankton (diatoms and dinoflagellates) and ciliates. Overall, the prey growth rates calculated in the control and the experimental chambers showed significantly that Halocynthia papillosa fed on all live carbon groups as well as detrital POC (Fig. 2); however, no significant decrease in DOC was detected.

Ash-free dry weight specific clearance rate values $\left(\mathrm{CR}_{\mathrm{AFDW}}, \mathrm{ml}\right.$ swept clear $\mathrm{g}$ AFDW ${ }^{-1} \mathrm{~h}^{-1}$, hereafter specific clearance rate) (i.e. the volume of water filtered by the ascidian to retain the observed decrease in number of cells, assuming a $100 \%$ retention efficiency) for each season and type of prey are shown in Fig. 3. Mean percentage decrease in prey concentration during the experiments was $65.6 \pm 12.3$ in summer, $25.9 \pm 6.3$ in fall, $16.3 \pm 5.6$ in winter, and $41.9 \pm 9.4$ in spring 


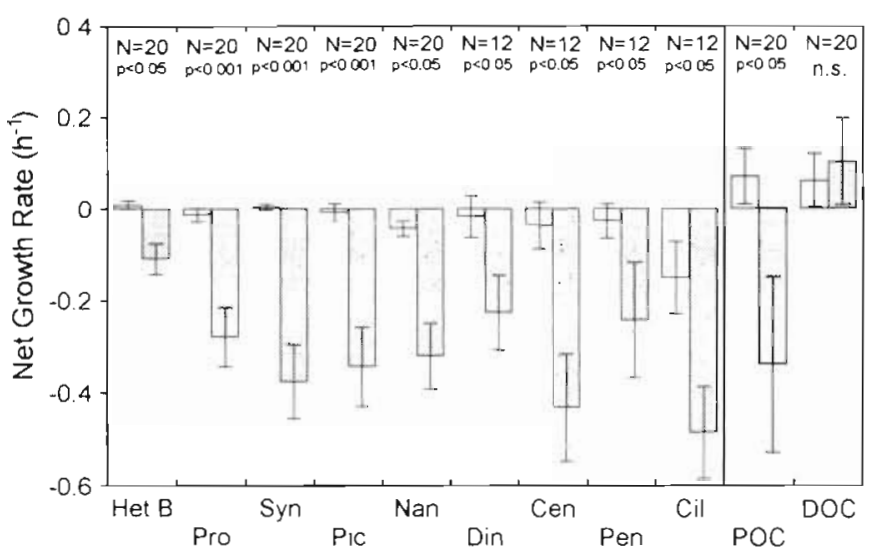

Fig. 2. Net growth rate of prey (mean \pm SE) in the experimental chamber ( $k_{\mathrm{a}}$, shaded bars) and in control chambers ( $k_{\mathrm{C}}$, open bars). Data are presented for each plankton group: Het B, heterotrophic bacteria; Pro, Prochlorococcus sp.; Syn, Synechococcus sp.; Pic, autotrophic picoeucaryotes; Nan, autotrophic nanoeucaryotes; Din, dinoflagellates; Cen, centric diatoms; Pen, pennate diatoms; Cil, ciliates; POC, detrital particulate organic carbon; DOC, dissolved organic carbon. Number of experiments and degree of significance from 2-tailed Wilcoxon test are shown. n.s.: not significant

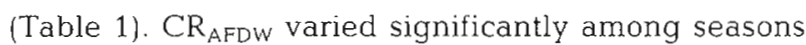
(Table 2), with the greatest values during summer (Duncan post-hoc test, $\mathrm{p}<0.005$ ). However, no significant differences were found in the $C_{\text {AFDW }}$ values between prey types (Table 2, Fig. 3).

The experiments, carried out seasonally, allowed coverage of the natural range of prey concentration (10 to $50 \mu \mathrm{g}$ live carbon $\mathrm{l}^{-1} ; 19$ to $813 \mu \mathrm{g} \mathrm{Cl}^{-1}$ of detrital origin) and almost the entire annual temperature range $\left(12\right.$ to $\left.23^{\circ} \mathrm{C}\right)$ of the study site (Ribes 1998). The effect of prey concentration (both from cells and detritus) and water temperature on $C R_{A F D W}$ of the species was assessed by focusing on the mean $C_{\text {AFDW }}$ value for all prey types in each experiment. $\mathrm{CR}_{\text {AFDW }}$ did not vary with food concentration within the natural range of cell and detritus concentration (multiple regression
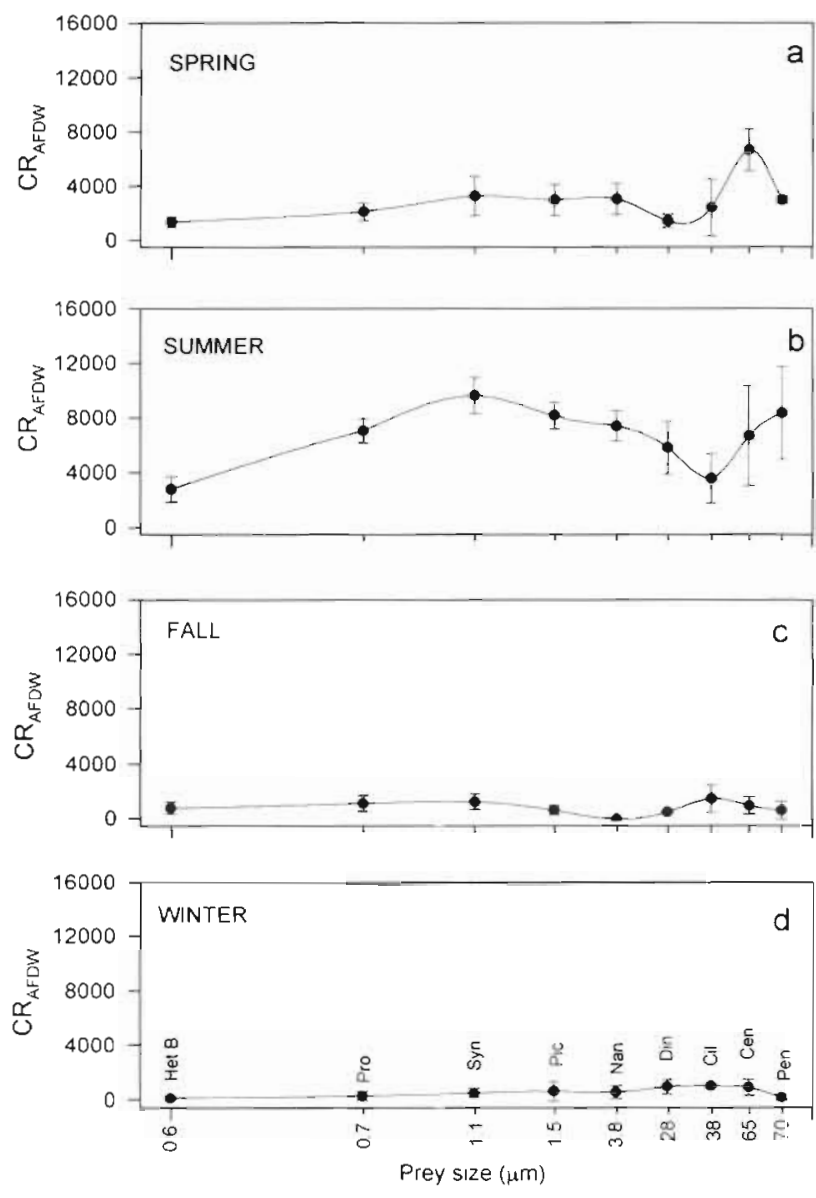

Fig. 3. Halocynthia papillosa seasonal specific clearance rate $\left(\mathrm{CR}_{\mathrm{AFDW}}\right.$; ml swept clear g AFDW ${ }^{-1} \mathrm{~h}^{-1}$, mean $\pm \mathrm{SE}$ ) as a function of prey size $(\mu \mathrm{m})$. Prey size is presented on a log scale. Prey abbreviations as in Fig. 2

analysis, $p>0.5$ for both variables). There was a marked pattern of $C R_{A F D W}$ increase with temperature increase (Fig. 4) and temperature variation explained $55 \%$ of the variance in $\mathrm{CR}_{\text {AFDW }}$ (multiple regression analysis, $n=20, p<0.0001$ ). The best fit to this pattern was a power function $\left(\mathrm{CR}_{\mathrm{AFDW}}=0.014 \mathrm{~T}^{4.33} ; \mathrm{T}\right.$ : water

Table 1. Initial prey concentration values for the 5 experiments in each season (mean $\pm \mathrm{SD}$ ). Het $\mathrm{B}$, Pro, Syn: $10^{3} \mathrm{cells}_{\mathrm{m}} \mathrm{m}^{-1} ; \mathrm{Pic}$, Nan: $10^{2}$ cells $\mathrm{ml}^{-1}$; diatoms (including centric and pennate), Din, Cil: $10^{3}$ cells $\mathrm{l}^{-1} \%$ change: percentage decrease in prey concentration of the final water samples with respect to the initial concentration

\begin{tabular}{|c|c|c|c|c|c|c|c|c|}
\hline Prey & \multicolumn{2}{|c|}{ Summer } & \multicolumn{2}{|c|}{ Fall } & \multicolumn{2}{|c|}{ Winter } & \multicolumn{2}{|c|}{$\begin{array}{c}\text { Spring } \\
\text { Concentration \% change }\end{array}$} \\
\hline Het B & $451 \pm 132$ & $46 \pm 20$ & $486 \pm 107$ & $19 \pm 11$ & $603 \pm 105$ & $9 \pm 1$ & $529 \pm 111$ & $22 \pm 9$ \\
\hline Pro & $3 \pm 0.9$ & $74 \pm 25$ & $23 \pm 13$ & $27 \pm 15$ & $5 \pm 2$ & $10 \pm 2$ & $1 \pm 0.2$ & $40 \pm 12$ \\
\hline Syn & $26 \pm 10$ & $78 \pm 23$ & $34 \pm 16$ & $30 \pm 18$ & $5 \pm 2$ & $12 \pm 3$ & $16 \pm 8$ & $43 \pm 16$ \\
\hline Pic & $10 \pm 5$ & $74 \pm 28$ & $9 \pm 1$ & $20 \pm 7$ & $31 \pm 5$ & $16 \pm 1$ & $12 \pm 9$ & $50 \pm 21$ \\
\hline Nan & $6 \pm 2$ & $70 \pm 20$ & $6 \pm 3$ & $23 \pm 9$ & $6 \pm 0.9$ & $20 \pm 3$ & $6 \pm 3$ & $49 \pm 19$ \\
\hline Diatoms & $6 \pm 4$ & $74 \pm 34$ & $9 \pm 7$ & $33 \pm 17$ & $19 \pm 4$ & $18 \pm 8$ & $49 \pm 10$ & $48 \pm 18$ \\
\hline Din & $3 \pm 0.2$ & $59 \pm 27$ & $2 \pm 0.8$ & $20 \pm 7$ & $3 \pm 0.5$ & $25 \pm 7$ & $3 \pm 1$ & $36 \pm 8$ \\
\hline Cil & $0.4 \pm 0.2$ & $50 \pm 19$ & $0.4 \pm 0.2$ & $35 \pm 10$ & $1 \pm 0.4$ & $20 \pm 13$ & $0.2 \pm 0.1$ & $47 \pm 20$ \\
\hline
\end{tabular}




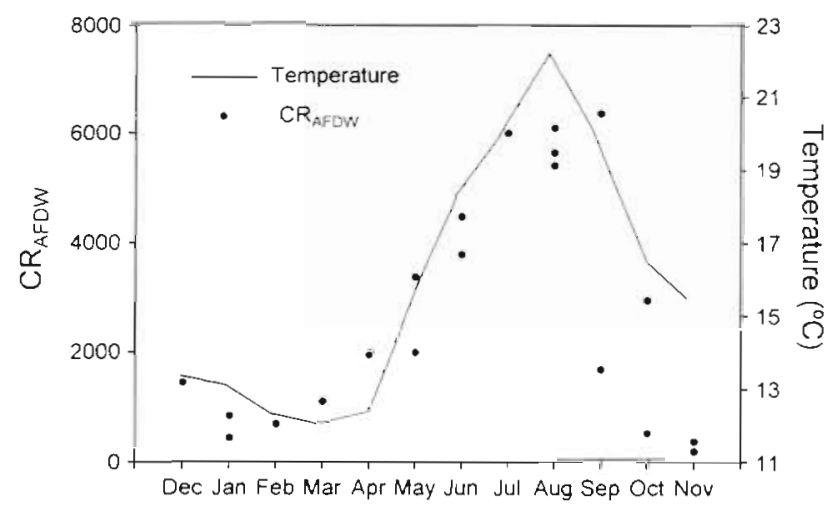

Fig. 4. Relationship between Halocynthia papillosa specific clearance rate (CR AFDWi ml swept clear $g$ AFDW ${ }^{-1} \mathrm{~h}^{-1}$ ) and temperature $\left({ }^{\circ} \mathrm{C}\right)$. Clearance rate assessed as the mean clearance rate value for all prey groups

temperature in ${ }^{\circ} \mathrm{C}$ ). The wide range of temperatures over which the grazing experiments were carried out $\left(13.7\right.$ to $22.6^{\circ} \mathrm{C}$ ) allowed the calculation of a $Q_{10}$ (sensu Fiala-Médioni 1978c) for the clearance rate. Because the temperatures did not differ by $10^{\circ} \mathrm{C}$, Van't Hoff's formula was applied $\left[Q_{10}=\left(\mathrm{CR}_{\mathrm{AFDW}_{2}} / \mathrm{CR}_{\mathrm{AFDW}_{1}}\right) /\left(10 / t_{2}-\right.\right.$ $t_{1}$ ); Lucas 1996]. A $Q_{10}$ value of 4.88 was estimated for the species.

In order to estimate the annual amount of carbon ingested by the species, monthly ingested carbon was calculated by applying the relationship between the specific clearance rate and temperature and using the mean monthly temperature and prey concentration values (Ribes 1998). Ingested organic carbon came from 2 main sources: carbon of detrital origin and carbon from live cells. An individual of Halocynthia papillosa of the studied size (mean $0.25 \mathrm{~g}$ AFDW) ingested an annual mean ( $\pm \mathrm{SE}$ ) of $1305 \pm 496 \mu \mathrm{g} \mathrm{C} \mathrm{g} \mathrm{AFDW}{ }^{-1}$ $\mathrm{h}^{-1}$ (Fig. 5a). Carbon of detrital origin accounted for $92 \pm 2 \%$ of the total ingested carbon and showed a marked seasonal pattern in which spring was the season with the highest values of ingestion $(4059 \pm 350 \mu \mathrm{g}$ $\mathrm{C} \mathrm{g} \mathrm{AFDW} W^{-1} \mathrm{~h}^{-1}$ ). Ingestion of live carbon accounted for $8 \pm 2 \%$ of the total carbon ingested, ranging from $0.8 \pm 0.3 \%$ in spring to $8 \pm 4 \%$ in winter (Fig. 5a). The highest values of live carbon ingestion occurred during summer and fall $\left(70 \pm 14\right.$ and $57 \pm 19 \mu \mathrm{g} \mathrm{C} \mathrm{g} \mathrm{AFDW}{ }^{-1}$

Table 2. Analysis of variance for specific clearance rates of Halocynthia papillosa between prey types and among seasons

\begin{tabular}{|lrrccc|}
\hline Source & df & SS & MS & $F$ & p \\
\hline Preytype & 9 & 3.01 & 0.329 & 1.119 & 0.358 \\
Season & 3 & 22.7 & 8.666 & 29.46 & $<0.0001$ \\
Interaction & 27 & 6.93 & 0.347 & 1.179 & 0.277 \\
Error & 88 & 21.91 & 0.294 & & \\
\hline
\end{tabular}
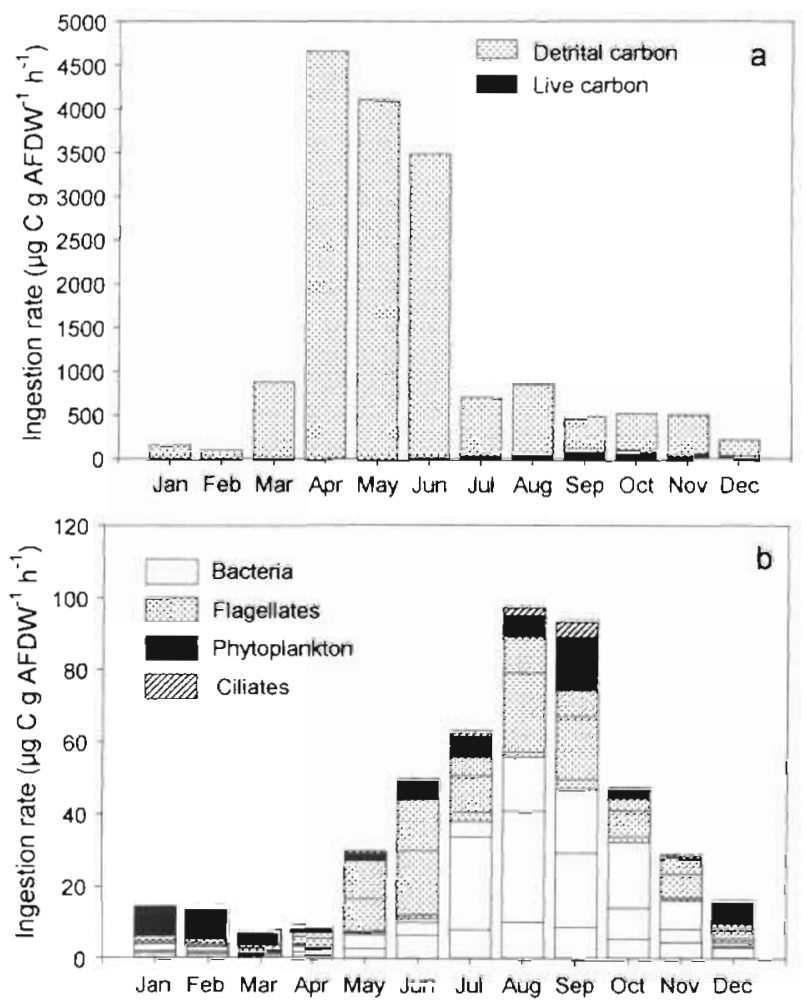

Fig. 5. Halocynthia papillosa. Monthly estimate of total organic carbon ingested throughout an annual cycle. (a) Total amount divided into the 2 main sources: live carbon and carbon from detrital origin. (b) Composition of the ingested live carbon. Bacteria include heterotrophic bacteria, Synechococcus sp. and Prochlorococcus sp. (from bottom to top and divided by lines across bar); flagellates include picoeucaryotes, autotrophic nanoeucaryotes and heterotrophic eucaryotes; phytoplankton include diatoms and dinoflagellates

$\mathrm{h}^{-1}$, respectively), which were about 4 times the ingestion during the winter and spring period $(15 \pm 1$ and $15 \pm 7 \mu \mathrm{g} \mathrm{C} \mathrm{g} \mathrm{AFDW}{ }^{-1} \mathrm{~h}^{-1}$, respectively). In summer and fall, bacteria accounted for about $45 \%$ of the total ingested live carbon. During winter phytoplankton

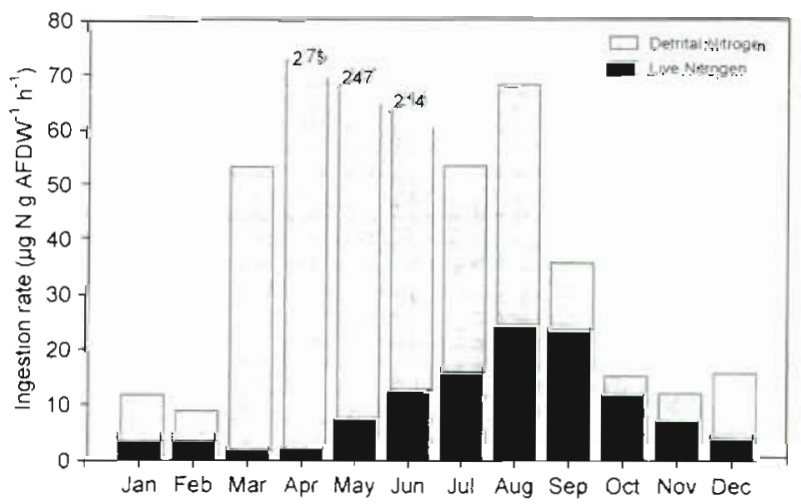

Fig. 6. Halocynthia papillosa. Sonthly estimates of total nitrogen (detrital and live) ingesif throughout an annual cle 

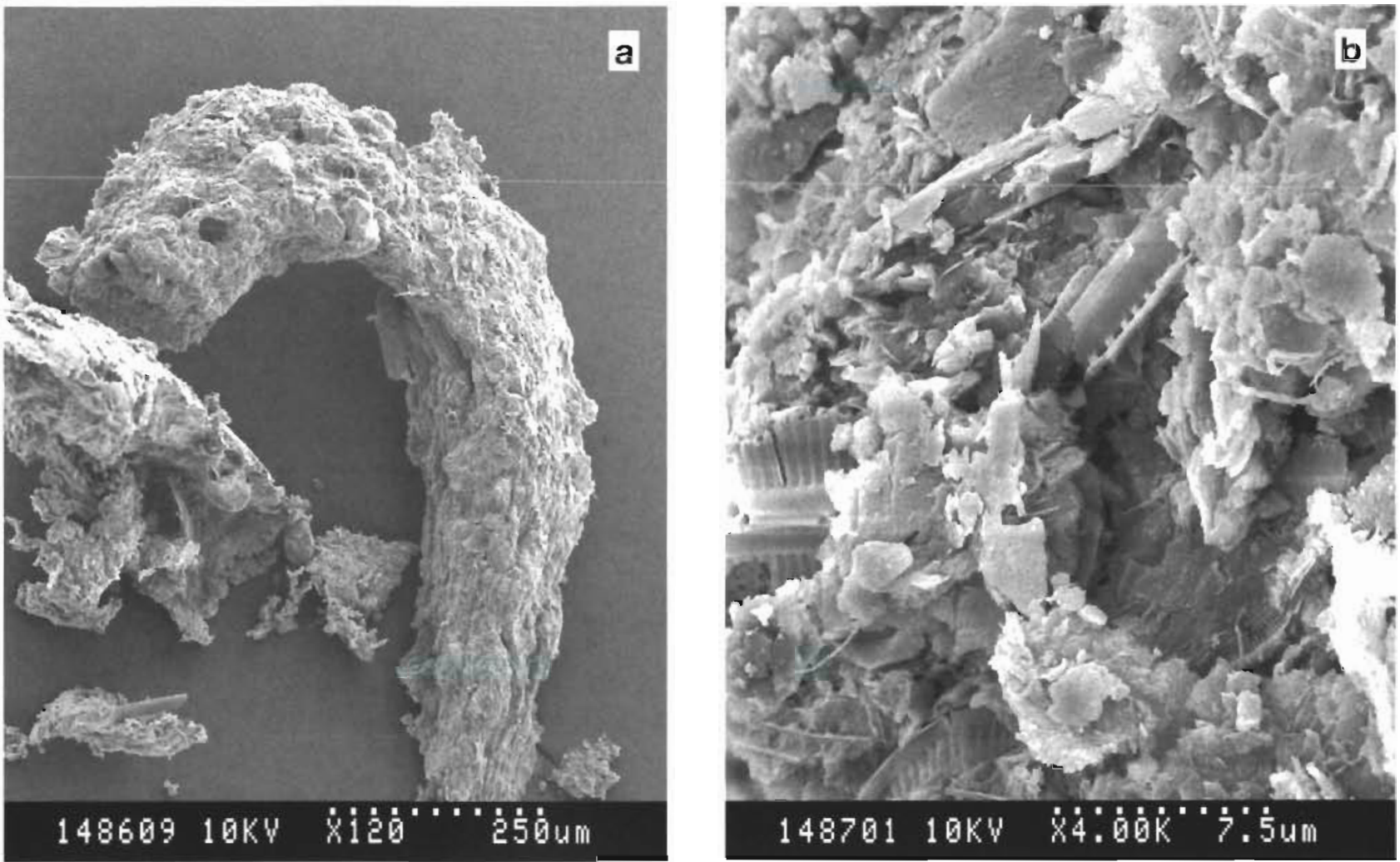

Fig. 7. Halocynthia papillosa. SEM observations of (a) ascidian feces, $\times 120$, and (b) detail of the feces composition showing several diatom fragments, $\times 4000$

accounted for over half of the total ingested live carbon and flagellates accounted for $50 \%$ of the total live carbon during spring (Fig, 5b).

The annual amount of nitrogen ingested by the species was calculated from the $\mathrm{C}$ : $\mathrm{N}$ ratios reported by Ribes (1998). An average C: $N$ of 4 was applied for the ingested live carbon and a C:N of 14 for the ingested detrital carbon. There was strong seasonality in the contributions of live particles and detritus as nitrogen sources (Fig, 6). During winter and fall, most nitrogen came from the live fraction (between 32 and $69 \%$ ). This pattern changed during spring and summer, when detrital particles were the main source of nitrogen for the species (98 and $76 \%$, respectively).

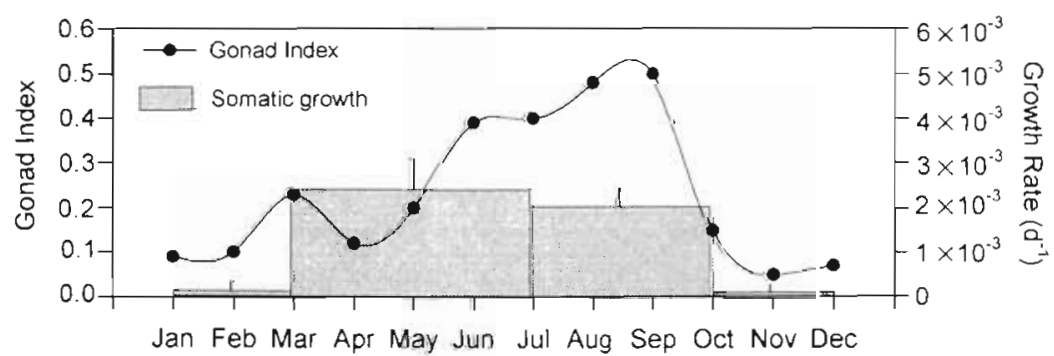

Fig. 8. Halocynthia papillosa. Monthly variation over an annual cycle of gonad index (data from Becerro \& Turon 1992) and somatic growth rate
On 4 occasions during the year-long experiments carried out, we observed the production of feces. Feces were about $3 \mathrm{~cm}$ long and thin (width approx $225 \mu \mathrm{m}$, Fig. 7a). Observations with an SEM of them showed a highly compacted structure, without a defined outer layer, within which it was possible to distinguish a large amount of diatoms and dinoflagellates fragments together with non-identifiable material (Fig. 7b). Examination of the gut contents of 20 freshly collected individuals showed similar results. On no occasion were zooplankton prey items or remains observed either in the feces or in the gut contents.

The growth rate of Halocynthia papillosa estimated from changes in the individual's area over time showed significant differences among seasons (Kruskal-Wallis test, $H=7.25$, df $=2$, $\mathrm{p}=0.026$ ). Maximum growth rate values were recorded in spring and summer and minimum in fall and winter (Fig. 8). The period with higher somatic growth in $H$. papillosa occurs at the same time as the period of higher gonadal development indicated by the gonad index (i.e. gonad weight/mantle weight; Becerro \& Turon 1992) of the species (Fig. 8). 


\section{DISCUSSION}

The natural diet of Halocynthia papillosa was highly heterogeneous, including live and detrital organic carbon. In size terms, this heterogeneous diet included the capture of a broad size range of food sources, from 0.6 (heterotrophic bacteria) to $70 \mu \mathrm{m}$ (pennate diatoms). The smallest particle size captured by Halocynthia papillosa is in accordance with the size of the branchial filters $(0.36$ to $1.16 \mu \mathrm{m}$ in diameter, Turon $1990 \mathrm{~b}$ ). In general, ascidians have been considered as non-selective suspension feeders for particles between 0.5 and $100 \mu \mathrm{m}$ (Fiala-Médioni 1987). These potential food sources are retained by the mucous net secreted by the endostyle in the pharyngeal cavity and afterwards transported as a food cord to the intestine (FialaMédioni 1978b, Flood \& Fiala-Médioni 1981). It has been pointed out that large particles (>100 $\mu \mathrm{m})$ usually do not reach the brachial cavity because of retention by the oral tentacles (Millar 1971, Klumpp 1984). However, some studies which examined the gut contents of ascidians have shown that some species consume a variety of invertebrate larvae and eggs (Young 1988, Bingham \& Walters 1989). Although this work was mainly focused on the study of prey items smaller than $100 \mu \mathrm{m}$, examination of the feces of the species showed a large amount of phytoplankton remains as well as non-identifiable material, but no zooplankton remains. Furthermore, no invertebrate larvae or egg remains were observed in the examination of the gut contents of the individuals examined in this study. These observations do not disprove that $H$. papillosa could be feeding on zooplankton to some extent.

The marked seasonal variation in the $\mathrm{CR}_{\text {AFDW }}$ of the species prompted the question of which environmental cues might influence its variability. As mentioned in the 'Introduction', temperature, food concentration, body size and oxygen tension have been suggested as the main factors that affect filtration rate (FialaMédioni 1978a, b, c, Robbins 1983, Klumpp 1984, Petersen \& Riisgård 1992). We did not examine the effect of oxygen tension on filtration rate of Halocynthia papillosa because all experiments were performed in the field, where oxygen concentration was always fully saturated or slightly supersaturated. Oxygen concentration during the incubation experiments was never allowed to decrease by more than $10 \%$ of the initial oxygen concentration, a fall in magnitude which appears not to affect the behavior of the ascidian. (Fiala-Médioni 1979a, Crisp 1984). Because specimens of similar size $(0.25 \pm 0.08 \mathrm{~g}$ AFDW $)$ were used in the experiments, the effect of body size on filtration rate was not examined. The experiments covered the natural range of prey concentration (10 to $50 \mu \mathrm{g}$ live

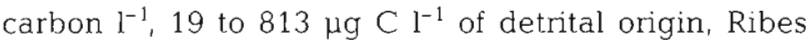

1998), and within this range $H$. papillosa $\mathrm{CR}_{\mathrm{AFDW}}$ was not significantly affected by food concentration. These results agree with previous studies carried out with graphite particles (Jorgensen 1955) and with food that resembles the composition of natural seston (Klumpp 1984). However, in laboratory studies, some authors have reported that food concentration affects filtration rate in ascidians, with a switching off of filtering at very low food concentrations and a satiation point at very high food concentrations (Fiala-Médioni 1979b, Robbins 1983, Klumpp 1984, Petersen \& Riisgărd 1992). Our results indicate that, in nature, there is a wide range of food concentrations over which filtration rate remains constant, although $H$. papillosa may exhibit different feeding behaviors at extreme food concentrations. Temperature appears to be the factor that best explains the $\mathrm{CR}_{\mathrm{AFDW}}$ seasonality. This result agrees with several previous laboratory studies (Holmes 1973, Fiala-Médioni 1978c, Robbins 1983, Petersen \& Riisgård 1992). The $Q_{10}$ estimated for $H$. papillosa represents a 5 -fold increase in clearance rate over the temperature range of 13.7 to $22.6^{\circ} \mathrm{C}\left(Q_{10}=4.88\right)$. This value is within the spread of values described for ascidian species studied to date, which ranges from 0.36 to 8.34 (Holmes 1973, Fiala-Médioni 1978c, Robbins 1983, Petersen \& Riisgård 1992). Our data suggest that the optimal temperature value for filtration activity of $H$. papillosa corresponds with the maximum temperature of the water in the annual cycle at the study site $\left(23^{\circ} \mathrm{C}\right)$. However, temperatures associated with maximum filtration activity may differ greatly between ascidian species (Fiala-Médioni 1978c).

The best fit of the relationship between clearance rate and temperature was a power function. In a previous study Petersen \& Riisgård (1992) found a linear relationship between clearance rate and temperature. This discrepancy could be related to several facts Petersen \& Risgård (1992) examined the effect of temperature on clearance rate under laboratory conditions and with a rather fast temperature change (i.e. hours or a few days). Our experiments represent a different approach to the effect of temperature on clearance rate because they were carried out over a year cycle with specimens that were always kept in their environment. In sublittoral temperate ecosystems, such as the one studied, temperature changes do not occur within a few days but over a longer time period, such as through the seasons. At this time scale, the organisms are subjected to physiological changes related to their cycle of production (i.e. growth and reproduction). In Halocynthia papillosa, the period of highest effect of temperature on clearance rate coincides with that of the highest gonadal development, which occurs during the warmest period of the year (Becerro \& Turon 1992). This coincidence is because temperature is one of the 
main factors regulating reproduction in this species (Becerro \& Turon 1992), as has been, in general, claimed for marine invertebrates (Orton 1920). We also observed that annual variation in growth rate suggests periods of highest growth correlate with those of highest gonadal development (Fig. 8). Therefore, our results are difficult to compare with those of Petersen \& Riisgård (1992) because they are subject to very different experimental conditions. Although a linear function might be expected from the relationship between temperature and clearance rate when all other parameters (such as ascidian size, reproduction period, etc.) remain constant, our data probably shows the added effect of both temperature and new production on clearance rate.

Although the positive effect of temperature on filtration rate appears to be a widespread characteristic of ascidian species, the mechanism that produces it is unclear. Some authors conducting laboratory experiments with other suspension feeders have interpreted low filtration rates at low temperatures as an energysaving adjustment. This serves to reduce the high costs of filter feeding during winter in temperate seas, when food concentrations are low (Newell \& Bayne 1980). This appears not to be the case in Halocynthia papillosa, because, although low filtration rates have been observed at low temperatures, the concentration of phytoplankton and detritus were high during the winter period (Ribes 1998). It has also been pointed out that the ascidian ciliary pharyngeal pump operates in the absence of physiological mechanisms to regulate water pumping, as is the case with suspension-feeding bivalves (Jørgensen et al. 1990). In this sense, Petersen \& Riisgård (1992) suggested that the increase of clearance rate in ascidians with temperature increase could correspond to a decrease in water viscosity.

Halocynthia papillosa ingestion rate also varied seasonally. The positive correlation between temperature and clearance rates together with the variation in food concentration throughout the year (Ribes 1998) explains the marked seasonality observed in the ingestion rate of the species. Maximum ingestion rates observed in spring were associated with the relatively high clearance rate and with the high abundance of seaweed detrital POC in the water column during this period (Ballesteros 1991, Ribes 1998). During the summer period, clearance rate increased but available POC decreased due to sedimentation (Ribes 1998). Thus, total ingestion rate decreased but the quality of the ingested material increased because sedimentation is more important for detrital POC than for live carbon. The low ingestion rate values during the winter months were mainly due to the decrease in clearance rate.
Table 3 shows $C R_{\text {AFDW }}$ values for different species and habitats. The wide range of $C R_{\text {AFDW }}$ reported for Halocynthia papillosa in this study was mainly due to variation in $\mathrm{CR}_{\mathrm{AFDW}}$ over the year. $\mathrm{CR}_{\mathrm{AFDW}}$ depends on variables such as body size (Klumpp 1984), temperature (Fiala-Médioni 1978c) and the methods used to obtain the $C R_{A F D W}$ values (Fiala-Médioni 1978a), making comparison between species difficult. However, in general, Mediterranean species appear to exhibit $\mathrm{CR}_{\text {AFDW }}$ values similar to those of estuarine and fjord species (Table 3). The lower $\mathrm{CR}_{\text {AFDW }}$ values reported for tropical species may be related to the fact that they are harboring symbiotic algae. These symbiotic ascidian species obtain an important portion of their carbon gain from the photosynthetically fixed carbon (Koike et al. 1993, Koike \& Suzuki 1996). Thus, they may only need to process a smaller water volume in order to cover their requirements.

Although the role of detritus in benthic invertebrate nutrition has been widely debated (Levinton et al. 1984), the fate and role of detritus derived from benthic marine macrophytes is an issue of considerable importance in coastal trophic dynamics (Tenore et al. 1982). Models of energy flow derived from estuarine systems suggest that detrital pathways are, by far, the dominant route by which seagrass production is utilized by higher trophic levels (e.g. Phillips 1984, Thayer et al. 1984). In general, attention has been focused on detritus produced by marine angiosperms (such as marsh and eelgrasses) and utilized by deposit-feeding invertebrates (Valiela 1995 and citations therein). However, detritus of macroalgal origin constitutes one of the main sources of the organic carbon pool in the study area (Ballesteros 1991, Ribes 1998), as has been reported in general for coastal waters (Mann 1982). Halocynthia papillosa filtered all items at equal rates, in accord with previous results obtained by Robbins $(1983,1984)$ that ascidian diets mirror the suspended food composition. Because detrital POC was always about an order of magnitude higher than live POC (Ribes 1998), organic carbon from detrital origin was the main source of ingested carbon throughout the year. Several studies have shown the importance of the origin of detritus for macroconsumers (Tenore et al. 1982, Crosby et al. 1989, Charles et al. 1996). In contrast with that of fecal pellets and vascular plants detritus, much of the potential energy of seaweed detritus is readily available (i.e. assimilable) to macroconsumers without the degradation of microbial organisms. Thus, although assimilation rates in ascidians have been shown to be much higher for phytoplankton cells (90\%, Fiala-Médioni 1973; 75\%, Klumpp 1984) than for organic carbon of detrital origin (42\%, Klumpp 1984), using the assimilation rates from Klumpp (1984) for both carbon sources, the annual mean organic 
Table 3. Clearance rate values (volumes in $\mathrm{ml}$ ) reported for different species of ascidians and different habitats. DW: dry weight DW $W_{w 1}$ dry weight without tunic. Indirect methods included: clearance (CR), flowmeter and hot film. Direct method: constant level tank. Methods terminology after Riisgård \& Larsen (1995)

\begin{tabular}{|c|c|c|c|c|c|}
\hline Species & $\mathrm{nlg} \mathrm{DW} \mathrm{W}^{-1} \mathrm{~h}^{-1}$ & 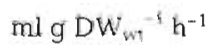 & Collection site & Observations & Source \\
\hline Aplidium altarium & 2600 & & Fijian seagrass & $\mathrm{CR}, 25-27^{\circ} \mathrm{C}$ & Koike \& Suzuki (1996) \\
\hline Ascidiella aspersa & & $3180-7800$ & Southampton estuary, UK & Flowmeter, $10^{\circ} \mathrm{C}$ & Holmes (1973) \\
\hline Ascidiella aspersa & & $3240-13200$ & Southampton estuary, UK & Flowmeter, $15^{\circ} \mathrm{C}$ & Holmes (1973) \\
\hline Ascidiella aspersa & & $2580-13500$ & Southampton estuary, UK & $\mathrm{CR}_{1} 15^{\circ} \mathrm{C}$ & Holmes (1973) \\
\hline Ascidiella aspersa & & 7153 & Limfjord, Denmark & $\mathrm{CR}, 20^{\circ} \mathrm{C}$ & Randlov \& Riisgărd (1979) \\
\hline Ciona intestinales & & 3517 & Mediterranean & $\mathrm{CR}, 15-16^{\circ} \mathrm{C}$ & Fiala-Médioni (1978a) \\
\hline Ciona intestinales & & 4331 & Mediterranean & $\mathrm{CR}, 15^{\circ} \mathrm{C}$ & Fiala-Médioni (1978a) \\
\hline Ciona intestinales & & 5906 & Mediterranean & Hot film, $15^{\circ} \mathrm{C}$ & Fiala-Médioni (1978a) \\
\hline Ciona intestinales & & 26430 & Danish fjord & $\mathrm{CR}, 15^{\circ} \mathrm{C}$ & Petersen \& Riisgard (1992) \\
\hline Ciona intestinales & & 10582 & Limfjord, Denmark & $\mathrm{CR}, 20^{\circ} \mathrm{C}$ & Randløv \& Riisgård (1979) \\
\hline Clavelina lepadiformis & & 2489 & Mediterranean & $\mathrm{CR}, 15-16^{\circ} \mathrm{C}$ & Fiala-Médioni (1974) \\
\hline Didemnum molle & 2000 & & Fijian seagrass & $\mathrm{CR}, 25-27^{\circ} \mathrm{C}$ & Koike \& Suzuki (1996) \\
\hline $\begin{array}{l}\text { Didemnum cf. } \\
\text { albopunctatum }\end{array}$ & 3600 & & Fijian seagrass & $\mathrm{CR}, 25-27^{\circ} \mathrm{C}$ & Koike \& Suzuki (1996) \\
\hline Halocynthia papillosa & & 6349 & Mediterranean & $\mathrm{CR}, 15-16^{\circ} \mathrm{C}$ & Fiala-Médioni (1974) \\
\hline Halocynthia papillosa & $162-4823$ & $594-17685$ & Mediterranean & $\mathrm{CR}, 12-22^{\circ} \mathrm{C}$ & This study \\
\hline Lissoclinum bistratum & 180 & & Fijian seagrass & $\mathrm{CR}, 25-27^{\circ} \mathrm{C}$ & Koike \& Suzuki (1996) \\
\hline Lissoclinum voeltzkowl & 70 & & Fijian seagrass & $\mathrm{CR}, 25-27^{\circ} \mathrm{C}$ & Koike \& Suzuki (1996) \\
\hline Microcosmus sabatieri & & 6909 & Mediterranean & $\mathrm{CR}, 15-16^{\circ} \mathrm{C}$ & Fiala-Médioni (1974) \\
\hline Phallusia mammillata & & 4380 & Mediterranean & $\mathrm{CR}, 15^{\circ} \mathrm{C}$ & Fiala-Médioni (1973) \\
\hline Phallusia mammillata & & 4779 & Mediterranean & $\mathrm{CR}, 15^{\circ} \mathrm{C}$ & Fiala-Médioni (1978a) \\
\hline Phallusia mammillata & & 6312 & Mediterranean & Hot film, $15^{\circ} \mathrm{C}$ & Fiala-Médioni (1978a) \\
\hline Pyura stolonifera & & $480-1260$ & South Africa & $\mathrm{CR}, 14^{\circ} \mathrm{C}$ & Klumpp (1984) \\
\hline Styela clava & & $4680-10500$ & Southampton estuary, UK & Flowmeter, $10^{\circ} \mathrm{C}$ & Holmes (1973) \\
\hline Styela clava & & $5760-14400$ & Southampton estuary, UK & Flowmeter, $15^{\circ} \mathrm{C}$ & Holmes (1973) \\
\hline Styela clava & & $1350-4200$ & Southampton estuary, UK & $\mathrm{CR}, 15^{\circ} \mathrm{C}$ & Holmes (1973) \\
\hline Styela clava & & 8881 & North Atlantic & Direct method, $15^{\circ} \mathrm{C}$ & Riisgård (1988) \\
\hline Styela plicata & & 8760 & Mediterranean & $\mathrm{CR}, 1.5^{\circ} \mathrm{C}$ & Fiala-Médioni (1978a) \\
\hline Styela plicata & & 10708 & Mediterranean & Hot film, $15^{\circ} \mathrm{C}$ & Fiala-Médioni (1978a) \\
\hline
\end{tabular}

carbon from detrital origin assimilated by $H$. papillosa was an order of magnitude higher than that obtained from live carbon (detrital origin: $714 \mu \mathrm{g} \mathrm{C} \mathrm{g} \mathrm{AFDW} \mathrm{AW}^{-1}$ $\mathrm{h}^{-1}$, live carbon: $21 \mu \mathrm{g} \mathrm{C} \mathrm{g} \mathrm{AFDW} \mathrm{W}^{-1} \mathrm{~h}^{-1}$ ). Nevertheless, because of its high $\mathrm{C}: \mathrm{N}$ ratio, the detrital pool is likely to represent a relatively poor nitrogen source for the species in comparison with live carbon (Tenore et al. 1982, Seiderer \& Newell 1985). In this sense, the annual mean consumption of nitrogen from live particles ingested by $H$. papillosa was of the same order of magnitude as that obtained from detrital particles (live particles [mean $\pm \mathrm{SE}$ ]: $10 \pm 2 \mu \mathrm{g} \mathrm{Ng} \mathrm{AFDW}{ }^{-1} \mathrm{~h}^{-1}$; detrital particles: $74 \pm 29 \mu \mathrm{g} \mathrm{N} \mathrm{g} \mathrm{AFDW}{ }^{-1} \mathrm{~h}^{-1}$ ). Furthermore, in some periods, such as fall, the importance of live particles as a source of nitrogen was higher than that of detrital particles. Thus, in the feeding ecology of $H$. papillosa, carbon obtained from procaryotes, pico- and nanoeucaryotes, phytoplankton and ciliates may be an essential source of nitrogen and others nutrients necessary for growth and reproduction, especially in certain periods of the year.

Annual variation in growth rate suggests periods of highest growth correlate with those of highest gonadal development. In order to assess the qualitative importance of the detrital and live particles, the seasonal pattern of both resources as a source of nitrogen was compared to that of gonadal development (but not to growth due to the wide sampling intervals). The seasonal variation of nitrogen of detrital origin did not significantly correlate with gonadal development during the year (multiple regression analysis, $\mathrm{p}=0.177$ ). However, the seasonal variation of nitrogen from live particles explained $91 \%$ of gonadal development variance (multiple regression analysis, $\mathrm{p}<0.0001$ ). These results suggest that live particles are likely to be of more significance in the diet of the species than particles from detrital origin. These results agree with those obtained by Seiderer \& Newell (1988) for the ascidian Pyura stolonifera in kelp beds. Thus, the main fraction of the particulate material present in the water column appeared to be relatively poorly exploited by some ascidian species, which has been suggested to be due to the lack of the necessary digestive enzymes (Seiderer \& Newell 1988).

This study has reported the diet and natural grazing rate of Halocynthia papillosa over an annual cycle, and has shown that growth and reproduction of the species mainly occur during spring and summer This fact is surprising because, in seasonal environments, the highest new production (i.e. growth and reproduction) 
usually occurs during periods of no limitation by external factors (i.e. temperature and food availability), and the Western Mediterranean in summer is characterized by oligotrophy and low seston concentration (Zabala \& Ballesteros 1989). However, different reasons suggost that food availability does not seem to be limiting. First, it has been recently shown that oligotrophy and low seston during the summer period in the Mediterranean entails mainly detrital POC, but the abundance of live particles remains rather constant through the year (Ribes 1998). Because the ingestion of live particles appears to be the main determinant of growth and reproduction, food availability should not significantly affect the species' secondary production. Furthermore, because food intake of the species was mainly dependent on $\mathrm{CR}_{\mathrm{AFDW}}$ seasonality (i.e. maximum $\mathrm{CR}_{\mathrm{AFDW}}$ during spring and summer), our work indicates that other factors (such as larval survival, competition, predation) rather than food concentration appear to be determining the seasonal dynamic in growth and reproduction of the species.

Acknowledgements. We especially thank Mikel Zabala and Enric Saiz for their help with this study. The manuscript was improved by the comments of Xavier Turon, Joan-Domènec Ros, Quim Garrabou and 3 anonymous reviewers. We thank Emma Cebrian for her help with phytoplankton counts. The flow cytometry measurements were carried out at the University of Hawai'i with the assistance of Hector Nolla. JoseManuel Fortuño assisted during SEM observations. POC and DOC analyses were provided by the Scientist Technical Service (University of Barcelona) with the assistance of I. Casals, P. Fernandez and L. Balart. Support for this work was provided by a F.P.I. fellowship from 'Ministerio de Educación y Ciencia' to M.R., by a MEC research contract to R.C., by a CICYT grant PB94-0014-C02-01 and by the MAST-IIIELOISE European Union METRO MED Project.

\section{LITERATURE CITED}

Ballesteros E (1991) Structure and dynamics of North-Western Mediterranean phytobenthic communities: a conceptual model. In: Ros J, Prat N (eds) Homage to Ramon Margalef or, Why there is such pleasure in studying nature. Oecol Aquat 10:223-242

Becerro MA, Turon X (1992) Reproductive cycles of the ascidians Microcosmus sabatieri and Halocynthia papillosa in the Nortwestern Mediterranean. PSZN I: Mar Ecol 13: $363-373$

Bingham BL, Walters LJ (1989) Solitary ascidians as predators of invertebrate larvae: evidence from gut analyses and plankton samples. J Exp Mar Biol Ecol 131:147-159

Bjørnsen PK (1986) Automatic determination of bacterioplankton biomass by image analysis. Appl Environ Microbiol 51:1119-1204

Campbell L, Nolla H, Vaulot D (1994) The importance of Prochlorococcus to community structure in the central North Pacific Ocean. Limnol Oceanogr 39:954-961

Charles F, Grémare A, Amouroux JM (1996) Ingestion rates and absorption efficiencies of Abra ovata (Mollusca: Bivalvia) fed on macrophytobenthic detritus. Estuar Coast
Shelf Sci 42:83-102

Clarke A (1987) Temperature, latitude and reproductive effort. Mar Ecol Prog Ser 38:89-99

Cloern JE (1982) Does the benthos control phytoplankton biomass in South San Francisco Bay? Mar Ecol Prog Ser 9: $191-202$

Crisp DJ (1984) Energy flow measurements. In: Holme NA, McIntyre AD (eds) Methods for the study of marine benthos. Blackwell Scientific Publications, Oxford, p 284-372

Crosby MP, Langdon CJ, Newell RIE (1989) Importance of the refractory plant material to the carbon budget of the oyster Crassostrea virginica. Mar Biol 100:343-352

Edler L (1979) Recommendations for marine biological studies in the Baltic Sea. Phytoplankton and chlorophyll. Baltic Mar Biol 5:5-38

Fiala-Médioni A (1972) Les peuplements sessiles des fonds rocheux de la région de Banyuls-sur-Mer: ascidiansbryozoaires (2ème partie et fin). Vie Milieu 23:143-182

Fiala-Médioni A (1973) Ethologie alimentaire d'invertébrés benthiques filtreurs (ascidians). I. Dispositif expérimental. Taux de filtration et de digestion chez Phallusia mammillata. Mar Biol 23:137-145

Fiala-Médioni A (1974) Ethologie alimentaire d'invertébrés benthiques filtreurs (ascidians). II. Variations des taux de filtration et de digestion en function de l'espèce. Mar Biol 28:199-206

Fiala-Médioni A (1978a) Filter-feeding ethology of benthic invertebrates (ascidians). IV. Pumping rate, filtration rate, filtration efficiency. Mar Biol 48:243-249

Fiala-Médioni A (1978b) A scanning electron microscope study of the branchial sac of benthic filter-feeding invertebrates (ascidians). Acta Zool 59:1-9

Fiala-Médioni A (1978c) Filter-feeding ethology of benthic invertebrates (ascidians). V. Influence of temperature on pumping, filtration and digestion rates and rhythms in Phallusia mammillata. Mar Biol 48:251-259

Fiala-Médioni A (1979a) Effects of oxygen tension on pumping, filtration and oxygen uptake in the ascidian Phallusia mammillata. Mar Ecol Prog Ser 1:49-53

Fiala-Médioni A (1979b) Influence de la concentration algale du milieu sur le pompage, la filtration et l'absorption de Phallusia mammillata (Cuvier, 1815) (Ascidie simple). Ann Inst Océanogr Paris 55:155-162

Fiala-Médioni A (1987) Lower chordates. In: Pandian TJ, Vernberg FJ (eds) Animal energetics, Vol 2. Academic Press, San Diego, p 323-356

Flood PR, Fiala-Médioni A (1981) Ultrastructure and histochemistry of the food trapping mucous film in benthic filter-feeders (ascidians). Acta Zool 62:53-65

Frost BW (1972) Effects of size and concentration of food particles on the feeding behaviour of the marine planktonic copepod Calanus pacificus. Limnol Oceanogr 17:805-815

Fry JC (1988) Determination of biomass. In: Austin B (ed) Methods in aquatic bacteriology. Wiley and Sons, New York, p 27-72

Gerdes D, Klages M, Arntz WE, Herman RL, Galéron J, Hain $S$ (1992) Quantitative investigations on macrobenthos communities of the southern Weddell Sea shelf based on multibox core samples. Polar Biol 12:291-301

Gili JM, Coma R (1998) Benthic suspension feeders: their paramount role in littoral marine food webs. Trends Ecol Evol 13:316-321

Harrison PS, Wallace CC (1990) Reproduction, dispersal and recruitment of scleractinian corals. In: Dubinsky $Z$ (ed) Ecosystems of the world 25. Coral reefs. Elsevier, Amsterdam, p 133-204

Hily $C$ (1991) Is the activity of benthic suspension feeders a 
factor controlling the water quality in the Bay of Brest? Mar Ecol Prog Ser 69:179-188

Holmes N (1973) Water transport in the ascidians Styela clava (Herdman) and Ascidiella aspersa (Müller). J Exp Mar Biol Ecol 11:1-13

Jørgensen CB (1955) Quantitative aspects of filter-feeding in invertebrates. Biol Rev 30:391-454

Jørgensen CB (1975) Comparative physiology of suspension feeding. Annu Rev Physiol 37:57-59

Jørgensen CB (1990) Bivalve filter feeding: hydrodynamics, bioenergetics, physiology and ecology. Olsen \& Olsen, Fredensborg

Jørgensen CB, Larsen PS, Riisgård HU (1990) Effects of temperature on the mussel pump. Mar Ecol Prog Ser 64:89-97

Kana T, Glibert PM (1987) Effect of irradiances up to $2000 \mu \mathrm{E}$ $\mathrm{m}^{-2} \mathrm{~s}^{-2}$ on marine Synechococcus WH 7803-I. Growth, pigmentation, and cell composition. Deep-Sea Res 34: $479-516$

Klumpp DW (1984) Nutritional ecology of the ascidian Pyura stolonifera: influence of body size, food quantity and quality on filter-feeding, respiration, assimilation efficiency and energy balance. Mar Ecol Prog Ser 19:269-284

Koike I, Suzuki T (1996) Nutritional diversity of symbiotic ascidians in a Fijian seagrass meadow. Ecol Res 11: $381-386$

Koike I, Yamamuro M, Pollard PC (1993) Carbon and nitrogen budgets of two ascidians and their symbionts, Prochloron, in a tropical seagrass meadow. Aust J Mar Freshwat Res $44: 173-182$

Levinton JS, Bianchi TS, Stewart S (1984) What is the role of particulate organic matter in benthic invertebrate nutrition? Bull Mar Sci 35:270-282

Lucas A (1996) Bioenergetics of aquatic animals. Taylor \& Francis, London

Mann KH (1982) Ecology of coastal waters. A system approach. Blackwel] Scientific Publications, Oxford

Massana R, Gasol JM, Björnsen PK, Blackburn N, Hagström A, Hietanen S, Hygum J, Kuparinen BH, Pedrós-Alió C (1997) Measurement of bacterial size via image analysis of epifluorescence preparations: description of an inexpensive system and solutions to some of the most common problems. Sci Mar 61:397-407

Millar RH (1971) The biology of ascidians. Adv Mar Biol 9: $1-100$

Monger BM, Landry MR (1993) Flow cytometric analysis of marine bacteria with Hoechst 33342. Appl Environ Microbiol 59:905-911

Montagnes DJ, Berges SJA, Harrison PJ, Taylor FJR (1994) Estimating carbon, nitrogen, protein and chlorophyll a from volume in marine phytoplankton. Limnol Oceanogr 39:1044-1060

Newell RC, Bayne BL (1980) Seasonal changes in the physiology, reproductive condition and carbohydrate content of the cockle Cardium (Cerastoderma) edule (Bivalvia: Cardidae). Mar Biol 56:11-19

Newell RC, Field JG, Griffiths CL (1982) Energy balance and significance of micro-organisms in a kelp bed community. Mar Ecol Prog Ser 8:103-113

Officer CB, Smayda TJ, Mann R (1982) Benthic filter feeding: a natura] eutrophication control. Mar Ecol Prog Ser 9: 203-210

Okamura B (1990) Behavioural plasticity in the suspension feeding of benthic animals. In: Hughes RN (ed) Behavioural mechanisms of food selection. Springer-Verlag, Berlin, p 637-660

Orton IH (1920) Sea temperature, breeding and distribution in marine animals. J Mar Biol Assoc UK 12:339-366
Petersen JK, Riisgård HU (1992) Filtration capacity of the ascidian Ciona intestinalis and its grazing impact in a shallow fjord. Mar Ecol Prog Ser 88:9-17

Petersen JK, Schou O, Thor P (1995) Growth and energetics in the ascidian Ciona intestinalis. Mar Ecol Prog Ser 120: $175-184$

Phillips RC (1984) The ecology of eelgrass meadows in the Pacific Northwest: a community profile. US Fish Wildl Serv, FSW/OBS-84/24

Putt $M$, Stoecker DK (1989) An experimentally determined carbon volume ratio for marine 'oligotrichous' ciliates from estuarine and coastal waters. Limnol Oceanogr 34 : $1097-1103$

Ramos AA (1988) Ascidias litorales del Mediterráneo Ibérico: faunística, ecología y biogeografía. PhD thesis, Univ of Barcelona

Randløv A, Riisgård HU (1979) Efficiency of particle retention and filtration rate in four species of ascidians. Mar Ecol Prog Ser 1.55-59

Ribes M (1998) Feeding activity and diet of benthic suspension feeders related to metabolic requirements and seston composition. PhD thesis, Unversity of Barcelona

Ribes M, Coma R, Gili JM (1998) Heterotrophic feeding by gorgonian corals with symbiotic zooxanthella. Limnol Oceanogr 43:1170-1179

Riisgård HU (1988) The ascidian pump: properties and energy cost. Mar Ecol Prog Ser 47:129-134

Robbins IJ (1983) The effects of body size, temperature, and suspension density on the filtration and ingestion of inorganic particulate suspensions by ascidians. J Exp Mar Biol Ecol 70:65-78

Robbins IJ (1984) The regulation of ingestion rate, at high suspended particulate concentrations, by some phleobranchiate ascidians. J Exp Mar Biol Ecol 82:1-10

Saiz E (1993) Sources of variability in zooplankton feeding experiments: the importance of accurate determination of algal growth rates. Sci Mar 57:23-29

Seiderer LJ, Newell RC (1985) Relative significance of phytoplankton, bacteria and plant detritus as carbon and nitrogen resources for the kelp bed filter-feeder Choromytilus meridionalis. Mar Ecol Prog Ser 22:127-139

Seiderer LJ, Newell RC (1988) Exploitation of phytoplankton as a food resource by the kelp bed ascidian Pyura stolonifera. Mar Ecol Prog Ser 50:107-115

Simon M, Azam F (1989) Protein content and protein synthesis rates of planktonic marine bacteria. Mar Ecol Prog Ser 51:201-213

Sokal RR, Rohlf FJ (1981) Biometry, 2nd edn. Freeman, San Francisco

Stuart V, Klumpp DW (1984) Evidence for food-resource partitioning by kelp-bed filter feeders. Mar Ecol Prog Ser 16 $27-37$

Tenore KR, Cammen L, Findlay SEG, Phillips N (1982) Perspectives of research on detritus: do factors controlling the availability of detritus to macroconsumers depend on its source? J Mar Res 40:473-490

Thayer GW, Kenworthy WJ, Fonseca MS (1984) The ecology of eelgrass meadows of the Atlantic coast: a community profile. US Fish Wildl Serv, FSW/OBS-84/02

Turon X (1988) The ascidians of Tossa de Mar (NE Spain) II. Biological cycles of the colonial species. Cah Biol Mar 29: $407-418$

Turon X (1990a) Distribution and abundance of ascidians from a locality on the Northeast Coast of Spain. PSZN I: Mar Ecol 11:291-308

Turon X (1990b) Estructura de los filtros branquiales de ascidias (Tunicados). Misc Zool 14:125-133 
Turon X (1992) Periods of non-feeding in Polysyncraton lacazel (Ascidiacea: Didemnidae): a rejuvenative process? Mar Biol 112:647-655

Turon X, Becerro MA (1992) Growth and survival of several ascidian species from the northwestern Mediterranean. Mar Ecol Prog Ser 82:235-247

Valiela I (1995) Marine ecological processes. Springer-Verlag, New York

Vaulot D, Partensky F, Neveus J, Mantoura RFC, Llewellyn $C$ (1990) Winter presence of prochlorophytes in surface waters of the northwestern Mediterranean Sea. Limnol Oceanogr 35:1156-1164

Editorial responsibility: Roger Hughes (Contributing Editor), Bangor, Gwynedd, Wales
Verity PG, Robertson CY, Tronzo CR, Andrews MG, Nelson JR, Sieracki ME (1992) Relationships between cell volume and the carbon and nitrogen content of marine photosynthetic nanoplankton. Limnol Oceanogr 37:1434-1446 Vogel S (1994) Life in moving fluids. The physical biology of flow. Princeton University Press, Princeton, NJ

Young CM (1988) Ascidian cannibalism correlates with larval behaviour and adult distribution. J Exp Mar Biol Ecol 117 : 9-26

Zabala M, Ballesteros E (1989) Surface-dependent strategies and energy flux in benthic marine communities or, why corals do not exist in the Mediterranean. Sci Mar 53:3-17

Submitted: June 1, 1998; Accepted: September 10, 1998

Proofs received from author(s): November 26, 1998 